\title{
Is there a market power in the Philippine rice industry?
}

\author{
Maria Hazel I. Bellezas ${ }^{1 *}$, Jose M. Yorobe Jr. ${ }^{2}$, Isabelita M. Paduayon ${ }^{2}$ \\ Prudenciano U. Gordoncillo ${ }^{2}$ and Antonio J. Alcantara Jr. ${ }^{3}$
}

\begin{abstract}
Submitted: 11 December 2018 | Accepted: 09 June 2020

Rice, as a staple food for the Filipinos, is widely studied from production to consumption. However, observations of the National Food Authority domestic procurement and price stabilization policy, as well as results of the marketing and market-related studies, still reveal some gaps which call forth for an in-depth investigation and analysis. One of these is the possible presence of market power, a market inefficiency in rice. Hence, this study aimed to ascertain the presence of market power in the Philippine rice industry. Secondary data published by the Philippine Statistics Authority from 1990 to 2015 were utilized. A structural econometric model using a time series approach was used in estimating the presence of market power. Results revealed the presence of market power in nonmajor rice-producing regions for well-milled and regular-milled rice, and for regularmilled rice in major rice-producing areas. The more the demand curve becomes inelastic the more the market power becomes apparent. The price elasticity of demand in the non-major rice-producing regions is -0.63 for both well-milled and regular-milled rice and -0.83 and -0.59 , respectively, in the major rice-producing areas. To minimize, if not solve market power, a substitute staple for rice may be introduced, programs/policies that will encourage more palay traders may be implemented, and farmers may be trained to operate like industry clusters.
\end{abstract}

Keywords: Bresnahan-Lau model, Market inefficiency, Price elasticity of demand, Philippine rice industry

Department of Economics, Visayas State University, Baybay City, Leyte, Philippines

${ }^{2}$ Department of Agricultural and Applied Economics, University of the Philippines at Los Baños, Laguna, Philippines

${ }^{3}$ School of Environmental Science and Management, University of the Philippines at Los Baños

Laguna, Philippines

*Corresponding Author. Address: Department of Economics, Visayas State University, Baybay City, Leyte, Philippines; Email:hazel.bellezas@vsu.edu.ph

DOI: $10.32945 /$ atr4228.2020 


\section{INTRODUCTION}

Rice is the staple food of the Philippine population, currently estimated at over 100 million and expanding $2 \%$ annually. Rice consumption is expected to grow moderately as the population continues to increase. Average per capita consumption from 2010-2014 is registered at 116kg per year (Philippine Statistics Authority (PSA) website).

The rice market in the Philippines is a shared responsibility of the government as represented by the National Food Authority (NFA) and the private sector, consisting of rice traders, commission agents, rice-millers, wholesalers, and retailers (Umali \& Duff 1992). The domestic rice prices have been directly influenced by the government through its monopoly on international trade and domestic marketing operations. The NFA sets the level of rice imports based on the estimated gap between rice production forecast and projected demand to ensure adequate rice supply and politically acceptable price levels. Domestic marketing operations are then undertaken by NFA to defend a uniform official floor price and retail price across seasons and geographic regions. The Asian Development Bank of the Philippines (ADB) in their study on the Philippine rice situation, however, notes that the Philippines still continues to wrestle with significant food insecurity. Despite government programs on rice self-sufficiency, rice supply and price stabilization are still a problem (Wailes \& Chavez 2012).

Observations made by Umali (1990), Yao et al (2007), and Intal et al (2012) revealed that the NFA domestic procurement and price stabilization policy for rice was ineffective regionally and nationally. It appears that the size and diversity of the rice market, relative to the modest scale of NFA activity, limits the program's influence on prices. It was found that nonlinearity in prices exists in several regions, particularly for farm gate prices. Further, studies reveal a very large gap between the price margins and the actual distribution costs between two markets - from the farm gate or producing market to the wholesale in the consuming market (Intal \& Ranit 2001), which indicates the existence of some monopoly or monopsony power of traders. The view that agricultural traders in the country wield monopsony and monopoly powers is expressed in terms of the so-called "Binondo rice cartel" (Intal \& Ranit 2001). The Binondo-based traders are the ultimate sources of informal agricultural credit given to farmers by the provincial, municipal, and 'barangaybased traders. The informal credit is linked to either the purchase of inputs or the sale of output by farmers. Thus, the rice cartel could exist both as a monopsonist and a monopolist and thereby exercise market power in rice trading. Intal and Ranit (2001) also cited the study of Dercon and Van Campenhout (1999) revealing a number of trade routes where price adjustment is sluggish, reaching up to 2.5 months duration - although the study reveals market integration in the long run. The slow pace of price adjustment between Western Visayas and Central Visayas may be attributed to a monopoly in shipping. However, the study of Rufino (2008) on spatial market integration of the different pairs of regional rice markets in the Philippines concludes that despite the geographic segregation of the regional rice markets and the presence of fragmented and often inefficient distribution systems, the price signals and other market information are transmitted efficiently across the markets, thus negating the potential occurrences of unexploited arbitrage opportunities. In addition, although price transmission is affected by seasonal 


\section{Is there a market power in the Philippine}

factors in farms and wholesale prices, at the national level and in surplus and deficit provinces, price shocks were immediately transmitted at all price levels, which suggests a strong correlation of farm, wholesale and retail prices (Ramos 2013).

Therefore, it is due to these diverse results that this study is undertaken. A complex and crucial industry like rice needs a number of models to finally address some of its issues and concerns. One important concern is the possible presence of market power in the rice industry. Determination of the presence of market power in the rice market will shed light on the supposition of the existence of monopoly/oligopoly in the rice industry. Therefore, this study's objective is to determine the presence of market power in the Philippine rice industry using the new empirical industrial organization approach. As a prime commodity in the country, a clearer and complete picture set for the industry is a good input for policymakers in improving its regulatory framework, especially in consonance with the big challenges it is facing - the welfare of the actors in the industry, food security and environment, and the ASEAN Free Trade Agreement.

\section{ANALYTICAL FRAMEWORK}

A typical structural approach uses a model with two basic equations: demand and marginal cost (Perloff et al 2007). The inverse demand function facing the market (or firm) is

$$
P=p(Q, Z),
$$

where $p$ is the price, $Q$ is the quantity of output, and $Z$ is a vector of exogenous variables (such as income and prices of substitutes) affecting the industry demand curve but not the marginal cost, though having some overlapping variables raises no additional problems. The marginal cost curve is

$$
M C=g(Q, w),
$$

where $w$ is a vector of exogenous variables (such as factor prices) that affect "industry" marginal cost but not the demand function. As cited by Perloff et al (2007), Just and Chen (1980), Bresnahan (1982), and Lau (1982) suggest that we use a conduct parameter, $\lambda$, to test various market structures. So, we can define an effective or perceived marginal revenue function as

$$
M R(\lambda)=P+\lambda P_{a}(Q, Z) Q,
$$

Where $\mathbf{P}_{\mathbf{a}}(\mathbf{Q}, \mathbf{Z})$ is the slope of the demand curve (the partial derivative with respect to $\mathbf{Q}$ ). If $\lambda=0$, marginal revenue equals price and the market is competitive; if $\lambda=1$, marginal revenue equals the marginal revenue of a monopoly; if $\lambda$ lies between 0 and 1 , the degree of market power lies between that of monopoly and competition, as in an oligopoly solution. With $\mathbf{n}$ identical firms in a Cournot (or Nash-in-quantities) equilibrium, $\lambda$ equals $1 / \mathbf{n}$.

The optimality or equilibrium condition is that the industry sets its effective marginal revenue, Equation (3), equal to its marginal cost, equation (2):

$$
M R(\lambda)=P+\lambda P_{a}(Q, Z) Q=M C(Q, w) .
$$


Bellezas et al

Thus, the basic model consists of a system of two equations, the demand Equation (1) and the optimality Equation (4).

Identification. Bresnahan (1982) and Lau (1982) gave conditions on the functional form such that $\lambda$ is identified. As Lau (1982) noted, the output can be written as a reduced-form equation of the exogenous variables, $Q=h_{1}(Z, w)$, and this equation is always identified. Given this functional relationship, the reduced-form expression of the price is

$$
P=p(Q, Z)=p\left(h_{1}(Z, w), Z\right)=h_{2}(Z, w),
$$

which is always identified. The optimality relationship is identified if, given an invariant demand function $p(Q, Z)$, it is not possible to find two distinct sets of the marginal cost function of the form $M C(Q, w)$ and $\lambda$ that satisfy equation (4). Bresnahan (1982), on the other hand, proposed rotation of the demand curve for market power to be identified. This framework is adopted in the studies of Ajide \& Aderemi 2015, for the Nigerian money market; Nwachukwu et al 2011, for the export demand of Nigerian cocoa; Celen \& Gunalp 2010, for the Turkish cement market; Susanto 2006 and Deodhar \& Sheldon 1997, for the export demand of soybean; Buchena \& Perloff 1991, for the Philippine coconut oil export market; and Karp \& Perloff 1989 for the rice export market. The rotation of the demand curve will have no effect on the equilibrium if pricing is competitive but will have an effect if there is market power. Thus, if we can rotate as well as shift the demand function, the hypotheses of competition and monopoly are distinct. So formally, the demand equation is changed to

$$
Q_{0}=\alpha_{0}+\alpha_{1} P+\alpha_{2} Y+\alpha_{3} P Z+\alpha_{4} Z+\varepsilon
$$

where $Z$ is a new demand-side exogenous variable. $Y$ might be interpreted as income. The key feature is that $Z$ enters interactively with $P$, so that changes in $Y$ and $Z$ combine elements both of rotation and vertical shifts in demand.

Now the supply relation has been altered to be

$$
P_{\square}=\frac{-\lambda}{\alpha_{1}+\alpha_{3} Z} Q+\beta_{0}+\beta_{1} Q+\beta_{2} W_{\square}+\eta
$$

Clearly, $\lambda$ is identified. The demand side is still identified. So, in attempting to disentangle $\lambda$ and $\beta_{1}$, in (7), we treat $\alpha_{1}$ and $\alpha_{3}$ as known. Writing $Q^{*}=-Q /\left(\alpha_{1}+\alpha_{3} Z\right)$, there are two included exogenous variables, $Q$ and $Q^{*}$. $Q *$ is the conduct variable for market power, and its coefficient $\lambda$ is the parameter of interest in determining the presence and degree of market power. 


\section{Is there a market power in the Philippine}

\section{METHODOLOGY}

The "new empirical industrial organization" (NEIO) typical studies use timeseries data from a single industry to estimate the presence of market power (Deodhar \& Sheldon 1997). The basic methodology of measuring market power under the NEIO is in the form of an oligopoly model, with three sets of unknown parameters: costs, demand, and firm conduct. The observable variables include industry price and quantity in time series for the endogenous variables and variables that shift cost and demand functions for the exogenous variables. Pricecost margins, on the other hand, are not taken to be directly observable. The structural econometric model to estimate market power was derived from Bresnahan (1982) and Lau (1982).

In this study, the behavior of traders was examined by separating the analyses into two: 1) major rice-producing regions and 2) non-major rice-producing regions. Since the bulk of palay (unmilled rice) supply comes from the major rice-producing regions, it is hypothesized that palay traders in the area are more influential in dictating rice prices than the traders in the non-major rice producing areas. The price setting in buying palay and rice is predominantly done by the traders (PSA 2015). In the study of PSA on Marketing Costs Structure for Palay/Rice 2013, seventy-eight percent (78\%) of the farm-operators responded that buyers usually set the price, and only $12 \%$ claimed that farmers and traders agreed on the selling price. On the side of the traders, $75 \%$ of the trader-respondents claimed that they set the price. Only $17 \%$ said that price was based on an agreement between buyers and traders (Philippine Statistics Authority 2015).

The secondary data used were gathered from the Philippine Statistics Authority website. Time series data from 1990 to 2015 were utilized.

\section{Estimating Supply and Demand for Rice in the Philippines}

Palay production in the Philippines is consistently dominated by the three major rice-producing regions: Central Luzon, Cagayan Valley, and Western Visayas (PSA data from 1990 to 2015). The other top palay producing regions are llocos Region, SOCCSKSARGEN, Bicol Region, MIMAROPA, and Eastern Visayas. The above eight regions contribute $77 \%$ of the total supply of palay. The second group of eight regions, namely Northern Mindanao, Davao Region, Zamboanga Peninsula, CAR, CALABARZON, CARAGA, ARMM, and Central Visayas, contributed only $23 \%$ of the total production. The first eight are considered in this study as the major riceproducing regions, and the rest of the regions of the country are the non-major riceproducing regions. The same model for the major rice-producing regions and nonmajor rice-producing regions was prepared with two datasets: one for well-milled rice and the other for regular-milled rice.

Adopting the structural model of Bresnahan (1982) and Lau (1982), the demand model of the study is:

$$
\boldsymbol{Q}=\alpha_{0}+\alpha_{1} \boldsymbol{P}_{\text {ri }}+\alpha_{2} \boldsymbol{C}_{\text {grits }}+\alpha_{3} \boldsymbol{S}_{\boldsymbol{p}}+\alpha_{\mathbf{4}} \boldsymbol{C}_{\boldsymbol{h}}+\alpha_{5} \boldsymbol{P}_{\mathbf{o}}+\alpha_{6} \boldsymbol{I}_{n c}+\alpha_{7} \boldsymbol{P}_{r i} \boldsymbol{I}_{n c}+\varepsilon
$$

and the linear marginal cost function:

$$
M C=\beta_{0}+\beta_{7} Q+\beta_{2} W_{s}+\beta_{3} R_{p}+\beta_{4} R_{\text {ain }}+\varepsilon
$$


where $Q$, is the quantity demanded/supplied for rice in grams per capita per quarter multiplied by the regional population; $P_{r i}$ market price (in metric tons) of well-milled or regular-milled rice per quarter; market prices (in metric tons) of a substitute and complementary goods per quarter such as corngrits $\left(\mathrm{C}_{\text {grits }}\right)$ and sweetpotato $\left(\mathrm{S}_{\mathrm{p}}\right)$, chicken $\left(C_{h}\right)$ and pork $\left(P_{o}\right)$; $I_{n c}$ for income in millions of pesos per quarter represented by the regional gross domestic product (RGDP) and $P_{r i} I_{n c}$ an interaction term (between the price of rice and RGDP). MC, on the other hand, is the marginal cost, which is a linear function of quantity $(Q)$, and the proxies for the cost incurred from the farm to the wholesaler $\left(W_{s}\right)$ and from the farm to the retailer $\left(R_{p}\right) . W_{s}$ is the ratio between the wholesale price of rice and the farmgate price of palay, and $R_{p}$ is the ratio between the retail price of rice and the farmgate price of palay. $R_{\text {ain }}$ is the rainfall data in millimeters. Data on rainfall is added to determine the influence of weather in the model. $\mathrm{C}_{\text {grits }}, \mathrm{S}_{\mathrm{p},}, \mathrm{C}_{\mathrm{h}}, \mathrm{P}_{\mathrm{o}}, \mathrm{I}_{\mathrm{n},}$ and $\mathrm{P}_{\mathrm{ri}} \mathrm{I}_{\mathrm{nc}}$ are the vectors of exogenous variables in the demand function while $W_{s}, R_{p}$, and $R_{a i n}$ are the vectors of exogenous variables in the marginal cost function. $\alpha$ and $\beta$ are parameters while $\varepsilon$ is the error term. The price data and the RGDP are in real terms.

Since the NEIO assumes that marginal cost is unobservable, the industry marginal cost function is free to assume alternative arbitrary forms, like the use of $\mathrm{W}_{\mathrm{s}}$ and $\mathrm{R}_{\mathrm{p}}$ in the model. These are not the industry's marginal costs but can represent cost shifters (Nwachukwu et al 2011). Price ratios were used as a proxy for costs.

To derive the supply relation, let total revenue be $R=P Q$. The marginal revenue is defined as $\mathrm{MR}=\mathrm{P}+(\partial \mathrm{P} / \partial \mathrm{Q}) \mathrm{Q}$. Inverting the demand function (8), one can obtain $\left.\partial \mathrm{P} / \partial \mathrm{Q}=-1 / \alpha_{1}+\alpha_{7} \mathrm{I}_{\mathrm{nc}}\right)$. Hence, $\mathrm{MR}=\mathrm{P}+\mathrm{Q}\left(-1 / \alpha_{1}+\alpha_{7} \mathrm{I}_{\mathrm{nc}}\right)$. By equating marginal revenue and marginal cost and inserting $\lambda$, the supply relation is written as

$$
\boldsymbol{P}_{r i}=\frac{-\lambda}{\alpha_{1}+\alpha_{7} \operatorname{Inc}} \boldsymbol{Q}+\beta_{0}+\beta_{1} \boldsymbol{Q}+\beta_{2} \boldsymbol{W}_{s}+\beta_{3} \boldsymbol{R}_{p}+\beta_{4} \boldsymbol{R}_{\text {ain }}+\eta
$$

By defining $Q^{*}=-Q /\left(\alpha_{1}+\alpha_{7} I_{\text {nc }}\right)$, equation (10) can be written as

$$
\boldsymbol{P}_{r i}=\lambda \boldsymbol{Q} *+\beta_{0}+\beta_{1} \boldsymbol{Q}+\beta_{2} \boldsymbol{W}_{s}+\beta_{3} \boldsymbol{R}_{\boldsymbol{p}}+\beta_{4} R_{\text {ain }}+\eta
$$

To disentangle $\lambda$ and $\beta_{1}$ in (11), $\alpha_{1}$ and $\alpha_{7}$ are treated as known through estimating the demand function first. Hence, $\lambda$ is identified as the coefficient of $Q^{*}$. $\lambda$ is expected to have a negative sign and $\beta_{s}$, positive. $\eta$ is an error term.

\section{Market Power Determination}

Finally, the demand function and supply relation of rice in the Philippines is written as follows:

$$
\begin{aligned}
& \boldsymbol{Q}=\alpha_{\mathbf{0}}+\alpha_{\mathbf{1}} \boldsymbol{P}_{\text {ri }}+\alpha_{2} \boldsymbol{C}_{\text {grits }}+\alpha_{3} \boldsymbol{S}_{\boldsymbol{p}}+\alpha_{\mathbf{4}} \boldsymbol{C}_{\boldsymbol{h}}+\alpha_{5} \boldsymbol{P}_{\mathbf{o}}+ \\
& +\alpha_{6} \text { Inc }+\alpha_{7} \boldsymbol{P}_{r i} \text { Inc }+\alpha_{8} \boldsymbol{T}+\varepsilon \\
& \boldsymbol{P}_{r i}=\beta_{0}+\beta_{1} \boldsymbol{P}_{r i t-1}+\beta_{2} \boldsymbol{Q}+\beta_{3} \mathbf{W}_{\mathrm{s}}+\beta_{4} \boldsymbol{R}_{\boldsymbol{p}}+\beta_{5} \boldsymbol{R}_{\text {ain }} \\
& +\lambda Q^{*}+\varepsilon
\end{aligned}
$$




\section{Is there a market power in the Philippine}

The demand function indicated above (12) was first determined in order to get the index for market power $(\lambda)$. The price and quantity of rice are in reduced form. Time is incorporated since all the variables in the demand function are I (1). Parallel to the demand function is the supply relation. A lagged variable on the price of rice was incorporated to see the effect of the previous price of rice on its current price. The presence of market power, the parameter of $Q^{\star}$, was observed by running an OLS regression of the supply relation.

\section{RESULTS AND DISCUSSION}

\section{The Demand Function}

The demand function for rice in major and non-major rice-producing regions are presented in Table 1 . The consumption of rice per capita multiplied by the population in the area was used for rice demand and prices for pork, chicken, corngrits, and sweetpotato for the complementary and substitute goods for rice. The regional gross domestic product was employed for the income criterion. All the variables used in the demand function are I (1); hence, the time element is included in the right-hand side of the equation. I (1) means the variable is non-stationary at the level form but stationary at 1 st difference. The Johansen tests for cointegration (please refer to Appendix Table $1 \mathrm{a} \& 1 \mathrm{~b}$ ) revealed that these I(1) variables are cointegrated; hence, the use of ordinary least squares is valid (Stock 1987).

One requisite for market power determination is the rotation of the demand curve, which can be exhibited through the interaction term - the regional gross domestic product and price of rice, in this case. The demand curve rotates if the coefficient of the interaction term is significant and negative. As shown in Table 1, the interaction term was negative and statistically significant at $1 \%$ level in both regions and type of rice.

Further, the demand model was subjected to a series of tests aside from an economic assessment of examining the signs of the parameters of the economic variables being used. Among the tests, an autocorrelation problem was found, thereby prompting the use of the generalized least squares. An autocorrelation problem will provide us with inefficient OLS estimates; hence, it is important to have ways of correcting our estimates (Gujarati 2004). The goodness of fit was high (99\%) for all groups, as expected for time series data (Table 1). The Autoregressive Conditional Heteroskedasticity (ARCH), heteroscedasticity and normality tests showed favorable results, such that the model is homoscedastic, errors are normally distributed and pass the Lagrange Multiplier (LM) test for autoregressive conditional heteroscedasticity.

Determinants of Demand for Rice. The demand for rice is influenced by a number of factors: a) the price of rice, b) prices of related goods which are either complementary (purchased along with) or substitutes (purchased instead of), c) the income of buyers, d) tastes and preferences, and lastly e) expectations. In this study, the top three were employed: the price of rice, income, and prices of related goods such as pork, chicken, corngrits, and sweetpotato. The income variable adopted was the gross domestic product of the region. 
Bellezas et al

Table 1. Regression (OLS) results for rice demand in major and non-major rice producing regions

\begin{tabular}{|c|c|c|c|c|}
\hline \multirow[b]{2}{*}{ Demand for Rice } & \multicolumn{2}{|c|}{ Major Rice Producing Regions } & \multicolumn{2}{|c|}{ Non-Major Rice Producing Regions } \\
\hline & $\begin{array}{l}\text { Well-milled } \\
\text { rice }\end{array}$ & $\begin{array}{l}\text { Regular-milled } \\
\text { rice }\end{array}$ & $\begin{array}{l}\text { Well-milled } \\
\text { rice }\end{array}$ & $\begin{array}{l}\text { Regular-milled } \\
\text { rice }\end{array}$ \\
\hline \multicolumn{5}{|l|}{ Retail Price (real data): } \\
\hline Rice & $\begin{array}{c}-4.9464^{\star \star \star} \\
(0.47262)\end{array}$ & $\begin{array}{l}-3.860 * \star \star \\
(0.567845)\end{array}$ & $\begin{array}{c}-3.89185^{\star \star \star} \\
(0.28212)\end{array}$ & $\begin{array}{r}-4.2921^{* \star *} \\
(0.38326)\end{array}$ \\
\hline Corn grits (white) & $\begin{array}{l}4.0481^{\star \star \star} \\
(0.31550)\end{array}$ & $\begin{array}{l}3.1151 * \star \star \\
(0.35219)\end{array}$ & $\begin{array}{c}2.1472^{\star \star \star} \\
(0.173788)\end{array}$ & $\begin{array}{l}2.6738^{\star \star \star} \\
(0.22947)\end{array}$ \\
\hline Sweetpotato & $\begin{array}{l}1.2570 \star \star \star \\
(0.23040)\end{array}$ & $\begin{array}{l}0.5827 * \star \\
(0.26537)\end{array}$ & $\begin{array}{l}0.5113^{\star \star \star} \\
(0.14236)\end{array}$ & $\begin{array}{c}0.53121 * \star \star \\
(0.17271)\end{array}$ \\
\hline $\begin{array}{l}\text { Dressed } \\
\text { chicken }\end{array}$ & $\begin{array}{l}-0.7584^{\star \star \star} \\
(0.05177)\end{array}$ & $\begin{array}{l}-0.6438 \star \star \star \\
(0.05395)\end{array}$ & $\begin{array}{c}-.722673^{\star \star \star} \\
(0.04562)\end{array}$ & $\begin{array}{l}-.68406 * \star \star \\
(0.05666)\end{array}$ \\
\hline Pork lean & $\begin{array}{l}0.2902^{\star \star \star} \\
(0.04179)\end{array}$ & $\begin{array}{l}0.2682^{\star \star \star} \\
(0.04972)\end{array}$ & $\begin{array}{c}.327758^{\star \star \star} \\
(0.05359)\end{array}$ & $\begin{array}{l}0.3078^{\star \star \star} \\
(0.06621)\end{array}$ \\
\hline $\begin{array}{l}\text { Real gross domestic } \\
\text { product }\end{array}$ & $\begin{array}{l}0.1983^{\star \star \star} \\
(0.01902)\end{array}$ & $\begin{array}{l}0.2402 * \star \star \\
(0.02004)\end{array}$ & $\begin{array}{c}0.13238 * \star \star \\
(0.00821)\end{array}$ & $\begin{array}{c}0.13589 * * * \\
(0.01006)\end{array}$ \\
\hline Gdp*price of rice & $\begin{array}{c}-1.71 \mathrm{e}-06^{\star \star \star} \\
(6.28 \mathrm{e}-07)\end{array}$ & $\begin{array}{c}-2.94 \mathrm{e}-06 * \star \star \\
(7.11 \mathrm{e}-07)\end{array}$ & $\begin{array}{c}-1.27 \mathrm{e}-06 \star \star \star \\
(3.11 \mathrm{e}-07)\end{array}$ & $\begin{array}{c}-1.80 \mathrm{e}-06^{\star \star \star} \\
(4.20 \mathrm{e}-07)\end{array}$ \\
\hline Time (quarterly) & $\begin{array}{c}88.6373 \\
(57.9720)\end{array}$ & $\begin{array}{c}52.7732 \\
(63.99218)\end{array}$ & $\begin{array}{l}73.23374 \\
(58.7724)\end{array}$ & $\begin{array}{l}108.5877 \\
(73.7128)\end{array}$ \\
\hline Constant & $\begin{array}{c}135760.6^{\star \star \star} \\
(12099.39)\end{array}$ & $\begin{array}{c}124045.5^{\star \star \star} \\
(12890.43)\end{array}$ & $\begin{array}{c}144149.4^{\star \star \star} \\
13278.6)\end{array}$ & $\begin{array}{r}130224 \star \star \star \\
(16512.64)\end{array}$ \\
\hline \multicolumn{5}{|l|}{ Diagnostic statistics: } \\
\hline R-squared (R2) & 0.9971 & 0.9964 & 0.9962 & 0.9941 \\
\hline $\begin{array}{l}\text { Breusch-Pagan/ Cook- } \\
\text { Weisberg test for } \\
\text { heteroscedasticity }\end{array}$ & $\begin{array}{c}\text { prob }>\chi 2= \\
0.0838\end{array}$ & $\begin{array}{c}\text { Prob }>\chi 2= \\
0.1392\end{array}$ & $\begin{array}{c}\text { Prob }>x 2= \\
0.2241\end{array}$ & $\begin{array}{c}\text { Prob }>\times 2= \\
0.5287\end{array}$ \\
\hline Durbin-Watson statistic & 1.8445 & 1.8138 & 1.8503 & 1.8454 \\
\hline $\begin{array}{l}\text { LM test for } \\
\text { autoregressive } \\
\text { conditional } \\
\text { heteroskedasticity } \\
\text { (ARCH) }\end{array}$ & $\begin{array}{c}\text { Prob }>\chi 2= \\
0.1785\end{array}$ & $\begin{array}{c}\text { Prob }>x 2= \\
0.3655\end{array}$ & $\begin{array}{c}\text { Prob }>\chi 2= \\
0.1591\end{array}$ & $\begin{array}{c}\text { Prob }>x 2= \\
0.4246\end{array}$ \\
\hline
\end{tabular}




\section{Is there a market power in the Philippine}

Table 1 continued

\begin{tabular}{lcccc}
\hline \multirow{2}{*}{ Demand for Rice } & \multicolumn{2}{c}{ Major Rice Producing Regions } & \multicolumn{2}{c}{ Non-Major Rice Producing Regions } \\
\cline { 2 - 5 } & Well-milled & Regular-milled & Well-milled & Regular-milled \\
& rice & rice & rice & rice \\
\hline Skewness/Kurtosis tests & Prob $>\chi 2=$ & Prob $>\chi 2=$ & Prob $>\chi 2=$ & Prob $>\chi 2=$ \\
for Normality & 0.9354 & 0.2585 & 0.4556 & 0.3390 \\
& & & & \\
Jarque-Bera normality & Prob $>\chi 2=$ & Prob $>\chi 2=$ & Prob $>\chi 2=$ & Prob $>\chi 2=$ \\
test: & 0.8653 & 0.5715 & 0.6025 & 0.4656 \\
\hline Note: Standard errors in parentheses. & &
\end{tabular}

Table 1 revealed that almost all the variables used showed the same level of significance (at $1 \%$ level). The influence of each determinant of demand was weighed in terms of own-price, cross-price, and income elasticities, as reflected in Table 3. As shown in the table, all the coefficients (absolute value) were below one implying inelasticity of demand. Inelastic demand signifies a less than $1 \%$ change (a decrease) in quantity demanded of rice per $1 \%$ change (an increase) in rice price. The same with the quantity demanded of complement and substitute goods, the change was less than $1 \%$ (a decrease or increase) of its demand if ever there was a $1 \%$ increase in the price of rice. For income elasticity, less than one and positive means that rice is a normal good and a necessity which truly corresponds to Filipinos' need for rice in every meal. Table 3 further reveals that corngrits, sweetpotato and pork are substitute goods for rice having a positive $(+)$ elasticity coefficient, and chicken serves as a complementary good, with negative (-) coefficient. The cross-price elasticity findings followed the standard results of the rice demand elasticities study of Lantican et al (2013) except for pork, which in this study becomes a substitute good for rice. Nevertheless, there is only a $0.3 \%$ increase in the demand for rice when the price of pork increases by $1 \%$, which might be attributed to the food budget. The price of lean pork is higher than other types of pork meat.

In terms of well-milled rice demand, the major rice-producing regions were less inelastic (or more elastic) than the non-major rice-producing regions $(-0.827$ \& 0.628 , respectively). This means that for every $10 \%$ increase in the price of rice, there was an $8.3 \%$ decrease in rice demand in major rice-producing regions compared to $6.3 \%$ in non-major rice-producing regions. This could be due to the fact that the latter regions, on the average, are high-income regions and are composed of more cities, thus consumers are exposed to more composite food offerings in food chains and malls leading to less rice preparation at home or in boarding houses. As a result, their quantity demands for rice is not so affected by price changes. In terms of cross-price elasticity for rice related goods, the major riceproducing regions are also more elastic except for pork where both regions and both types of rice revealed the same results.

Regular-milled rice (RMR) is of lower quality than well-milled rice (WMR). For both groups, a difference of 0.036 and less inelasticity may mean the same ownprice and cross-price elasticity for RMR in both regions (major \& non-major riceproducing regions). If we connect the buyers of RMR to the low-income rice consumers, then their buying behavior for rice is the same regardless of where they are located. 
Bellezas et al

Table 2. Regression (OLS) results of rice supply in major and non-major rice producing regions

\begin{tabular}{|c|c|c|c|c|}
\hline \multirow[b]{2}{*}{ Supply Relation } & \multicolumn{2}{|c|}{ Major Rice Producing Regions } & \multicolumn{2}{|c|}{ Non-Major Rice Producing Regions } \\
\hline & $\begin{array}{l}\text { Well-milled } \\
\text { rice }\end{array}$ & $\begin{array}{l}\text { Regular-milled } \\
\text { rice }\end{array}$ & $\begin{array}{l}\text { Well-milled } \\
\text { rice }\end{array}$ & $\begin{array}{l}\text { Regular-milled } \\
\text { rice }\end{array}$ \\
\hline $\begin{array}{l}\text { L.Retail Price of } \\
\text { Rice }\end{array}$ & $\begin{array}{c}0.70138 * \star \star \\
(0.08941)\end{array}$ & $\begin{array}{l}0.709864 \star \star \star \\
(0.083423)\end{array}$ & $\begin{array}{l}0.71108 * \star \star \\
(0.08349)\end{array}$ & $\begin{array}{c}0.625142^{\star \star \star} \\
(0.080196)\end{array}$ \\
\hline Quantity supplied & $\begin{array}{c}0.1531298 \\
(0.10528)\end{array}$ & $\begin{array}{l}0.222743^{\star *} \\
(0.093599)\end{array}$ & $\begin{array}{l}0.11801^{\star \star \star} \\
(0.040814)\end{array}$ & $\begin{array}{l}.097169 \star \star \star \\
(0.027429)\end{array}$ \\
\hline $\begin{array}{l}\text { Presence of } \\
\text { Market power }\end{array}$ & $\begin{array}{l}-0.8618609 \\
(0.634456)\end{array}$ & $\begin{array}{l}-0.991042 \star * \\
(0.414493)\end{array}$ & $\begin{array}{l}-0.69454^{\star \star \star} \\
(0.24026)\end{array}$ & $\begin{array}{l}-.728265^{\star \star \star} \\
(0.199444)\end{array}$ \\
\hline $\begin{array}{l}\text { Ratio for } \\
\text { wholesale price } \\
\text { over farmgate } \\
\text { price }\end{array}$ & $\begin{array}{c}35561.2^{\star \star \star} \\
(7324.50)\end{array}$ & $\begin{array}{l}31693.9 * * * \\
(7856.198)\end{array}$ & $\begin{array}{c}10092.6^{\star \star} \\
(4970.243)\end{array}$ & $\begin{array}{c}27406.6^{\star \star \star} \\
(5239.44)\end{array}$ \\
\hline $\begin{array}{l}\text { Ratio for retail } \\
\text { price over } \\
\text { farmgate price }\end{array}$ & $\begin{array}{c}-29202.1^{\star \star \star} \\
(5182.35)\end{array}$ & $\begin{array}{c}-26381.2^{\star \star \star} \\
(5918.08)\end{array}$ & $\begin{array}{l}-7698.9 * \\
(4139.44)\end{array}$ & $\begin{array}{l}-21474.8^{\star \star \star} \\
(4262.09)\end{array}$ \\
\hline Rainfall & $\begin{array}{c}-0.0086329 \\
(0.01538)\end{array}$ & $\begin{array}{l}0.0056665 \\
(0.013887)\end{array}$ & $\begin{array}{l}-0.0098493 \\
(0 . .018037)\end{array}$ & $\begin{array}{l}-.0231097 \\
(0.01428)\end{array}$ \\
\hline Constant & $\begin{array}{l}496.0369 \\
(3686.80)\end{array}$ & $\begin{array}{l}4578.397 \\
(3762.60)\end{array}$ & $\begin{array}{c}7404.748^{\star \star} \\
(3415.19)\end{array}$ & $\begin{array}{l}5133.69 * * \\
(2489.66)\end{array}$ \\
\hline Diagnostic statistics: & & & & \\
\hline R-squared $\left(\mathrm{R}^{2}\right)$ & .9029 & .9000 & 0.9174 & 0.9332 \\
\hline $\begin{array}{l}\text { Breusch-Pagan/ Cook- } \\
\text { Weisberg test for hetero } \\
\text { scedasticity }\end{array}$ & Robust SE & Robust SE & Robust SE & Robust SE \\
\hline $\begin{array}{l}\text { Breusch-Godfrey LM } \\
\text { test for autocorrelation }\end{array}$ & $\begin{array}{l}\text { Prob }>\chi^{2}= \\
0.1649\end{array}$ & $\begin{array}{l}\text { Prob }>\chi^{2}= \\
0.4970\end{array}$ & $\begin{array}{l}\text { Prob }>\chi^{2}= \\
0.6617\end{array}$ & $\begin{array}{l}\text { Prob }>\chi^{2}= \\
0.4326\end{array}$ \\
\hline $\begin{array}{l}\text { Durbin-Watson statistic } \\
\text { (alternative statistics) }\end{array}$ & $\begin{array}{l}\text { Prob }>x 2= \\
0.1782\end{array}$ & $\begin{array}{l}\text { Prob }>\chi 2= \\
0.5133\end{array}$ & $\begin{array}{l}\text { Prob }>x 2= \\
0.6740\end{array}$ & $\begin{array}{l}\text { Prob }>x 2= \\
0.4497\end{array}$ \\
\hline $\begin{array}{l}\text { LM test for } \\
\text { autoregressive } \\
\text { conditional } \\
\text { heteroskedasticity } \\
\text { (ARCH) }\end{array}$ & $\begin{array}{l}\text { Prob }>\times 2= \\
0.9874\end{array}$ & $\begin{array}{l}\text { Prob }>\chi 2= \\
0.6594\end{array}$ & $\begin{array}{l}\text { Prob }>\times 2= \\
0.7525\end{array}$ & $\begin{array}{l}\text { Prob }>\times 2= \\
0.9566\end{array}$ \\
\hline $\begin{array}{l}\text { Skewness/Kurtosis } \\
\text { tests for Normality }\end{array}$ & $\begin{array}{l}\text { Prob }>x 2= \\
0.0000\end{array}$ & $\begin{array}{l}\text { Prob }>x 2= \\
0.0000\end{array}$ & $\begin{array}{l}\text { Prob }>x 2= \\
0.0000\end{array}$ & $\begin{array}{l}\text { Prob }>x 2= \\
0.0000\end{array}$ \\
\hline $\begin{array}{l}\text { Jarque-Bera normality } \\
\text { test: }\end{array}$ & $\begin{array}{l}\text { Prob }>\times 2= \\
2.8 \mathrm{e}-40\end{array}$ & $\begin{array}{l}\text { Prob }>\chi 2= \\
1.5 e-30\end{array}$ & $\begin{array}{c}\text { Prob }>\times 2= \\
4 . e-137\end{array}$ & $\begin{array}{l}\text { Prob }>\times 2= \\
1 . e-123\end{array}$ \\
\hline
\end{tabular}




\section{Is there a market power in the Philippine}

Table 3. Own-price, cross-price and income elasticity of demand for rice

\begin{tabular}{lcccc}
\hline \multirow{2}{*}{ Elasticity } & \multicolumn{2}{c}{ Major Rice Producing Regions } & \multicolumn{2}{c}{ Non-Major Rice Producing Regions } \\
\cline { 2 - 5 } & Well-milled rice & Regular-milled rice & Well-milled rice & Regular-milled rice \\
\hline Rice & -0.827 & -0.585 & -0.628 & -0.625 \\
Corngrits & 0.531 & 0.282 & 0.364 & 0.313 \\
Sweetpotato & 0.139 & 0.057 & 0.063 & 0.058 \\
Chicken & -0.568 & -0.541 & -0.432 & -0.459 \\
Pork & 0.255 & 0.288 & 0.222 & 0.255 \\
Regional GDP & 0.310 & 0.207 & 0.815 & 0.461 \\
\hline
\end{tabular}

Regarding income elasticity, all regions have inelastic results and are positive, although results showed that rice consumers for WMR and RMR in non-major riceproducing regions are more responsive to an increase in income than major-rice producing regions. Meaning, if there is a one percent increase in income, rice consumers in the non-major rice-producing regions will buy more units of rice (WMR or $\mathrm{RMR})$ than in major rice-producing regions $(0.815 \& 0.461$ vs $0.310 \& 0.207$, respectively). This might be attributed to the fact that non-major rice-producing regions are deficit regions, with high-income groups and rice is a normal good. But it can be noted, however, that the increase in rice demand when income increases may not be for greater quantity of rice but a shift to a better quality higher price rice (WMR).

\section{The Rice Supply Function}

The rice supply function shown in Table 2 includes a one lag price of rice to the right-hand side of the equation to determine the influence of the previous price to the current price of rice. The other regressors are the quantity supplied of rice, rainfall data, the rice price ratio (wholesale price over farmgate price \& retail price over farmgate price), and the index for a market power determination - the central reason why this study is conceived. The price ratios were used as a proxy for the costs incurred in the marketing channel of rice. Except for the price and quantity demanded rice, all the variables used in the supply relation were already stationary.

As revealed in the specification tests in Table 2, there was no problem of serial correlation, so the estimation was consistent. The weighted least squares, however, were adopted because of the problem of heteroscedasticity. The DurbinWatson alternative tests for autocorrelation, Breusch-Godfrey LM test for autocorrelation, as well as the LM test for autoregressive conditional heteroscedasticity $(\mathrm{ARCH})$ all showed favorable results. Results of Skewness/Kurtosis tests for normality as well as the Jarque-Bera normality tests, however, showed a $1 \%$ level of significance. Meaning, the model was not normally distributed as usually observed in heteroscedastic models (Table 2). This was then, however, solved through robust regression. 
Presence of Market Power. Market power is the ability of a firm to raise the market price of a good or service over marginal cost. In the case of the Philippine rice industry, its presence was ascertained by calculating an index for market power patterned from the approach used by Bresnahan (1982) and Lau (1982). Adopting this model was first done in the Philippines and first for the rice industry. Digal LN (2011) studied market power in the Philippine retail and processed food industry using price transmission and price asymmetry models. Kang et al (2009), on the other hand, studied market power in the world rice market but used the CR4 (a fourfirm concentration ratio) and $\mathrm{HHI}$ (Herfindal Index) while Karp \& Perloff (1989) used a linear-quadratic dynamic oligopoly model.

In the Brenahan-Lau model, if the coefficient of the index for market power is negative and significant, then market power exists. Table 2 reveals the final results. As shown, the index for market power was statistically significant at $1 \%$ level in nonmajor rice-producing regions for both types of rice - the WMR and RMR. In the major rice-producing regions, RMR is significant at a $5 \%$ level, while the result was not significant for WMR.

The above revelation could be attributed to the fact that the non-major rice producing regions are the rice deficit regions comprising of more cities with generally high income and dense population. The rice demand of this group is high. Given that rice is a staple food, demand in these areas is steeper, and price flexibility is higher. Also, the non-major rice producing regions are paying a higher price of rice for both types - WMR and RMR - and lower farmgate price of palay. These regions are also recipients of the imported and most likely the smuggled rice. The far cheaper imported rice enable the rice sellers or firms in this group to reap more profit than their counterparts in major rice-producing regions because they can buy rice at a lower price and sell it based on the prevailing price of rice.

Table 2 further reveals that there is market power in lower-priced and lowerquality rice compared to well-milled rice, and is distinct in major rice producing areas. The price of RMR, although a bit lower fluctuates the same as WMR, and the price difference is constant through the years, indicating that the price for RMR is probably based on the price of WMR - just lowered slightly because of more broken rice after being milled.

Furthermore, price theory tells us that government intervention can create market failure. Therefore, government programs for the rice industry may have contributed to this kind of market inefficiency. A study of Yao et al (2007) reveals that although the NFA could have achieved its objective of increasing farmgate prices at the national level and decreasing retail prices in five regions, its interventions did not help to stabilize prices and, on balance, are associated with a higher retail rice price in most regions of the country. According to Balisacan et al as cited by Reeder 2000, relief coming from imports has been ineffective as poorly timed disbursements of imported rice have often resulted in either too much or too little rice in the market further aggravating an already fragile market. The study of Intal Jr et al (2012) supports the above results. As revealed, NFA has been unsuccessful in stabilizing producer prices, but relatively successful in stabilizing retail prices, largely through the exercise of its import monopoly.

Nevertheless, the degree of the distortion that the program has inflicted may be insignificant amidst the number of players in the rice industry with product differentiation in the form of brands for special rice, packaging, and quality (RMR \& WMR) so that evaluation studies on market performance unveiled varied results. In 


\section{Is there a market power in the Philippine}

this study, however, it was discovered that the more the demand curve becomes inelastic, the more the market power becomes apparent. As shown in Table 4, there was no market power for WMR $\left(\varepsilon_{\mathrm{d}}=-0.83\right)$ in the major rice-producing regions, but it was obvious for RMR $\left(\varepsilon_{\mathrm{d}}=-0.59 \&-0.63\right)$ in both regions and WMR $\left(\varepsilon_{\mathrm{d}}=-0.63\right)$ in the non-major rice areas. Rice sellers in the latter groups reap more profits as a result of market power.

Table 4. Market power and own-price elasticity of demand for rice

\begin{tabular}{|c|c|c|c|c|}
\hline \multirow[b]{2}{*}{ Item } & \multicolumn{2}{|c|}{ Major Rice Producing Regions } & \multicolumn{2}{|c|}{ Non-Major Rice Producing Regions } \\
\hline & $\begin{array}{l}\text { Well-milled } \\
\text { rice }\end{array}$ & $\begin{array}{c}\text { Regular-milled } \\
\text { rice }\end{array}$ & $\begin{array}{c}\text { Well-milled } \\
\text { rice }\end{array}$ & $\begin{array}{l}\text { Regular-milled } \\
\text { rice }\end{array}$ \\
\hline Market power index & -0.862 & $-0.991^{* *}$ & $-0.695^{* * *}$ & $-.728^{* * *}$ \\
\hline $\begin{array}{l}\text { Price elasticity } \\
\text { (without interaction term) }\end{array}$ & -0.83 & -0.59 & -0.63 & -0.63 \\
\hline $\begin{array}{l}\text { Price elasticity } \\
\text { (with interaction term) }\end{array}$ & -0.88 & -0.67 & -0.72 & -0.74 \\
\hline
\end{tabular}

In addition, in non-major rice-producing areas, the index for market power for WMR and RMR was statistically significant at $1 \%$ level. These are the deficit areas, and as noted in Table 2, the price of rice is considerably affected by the supply of rice at $1 \%$ level of significance. Being dependent on rice supply from other areas, their demand for rice staple is somewhat steeper. A steeper demand curve has larger market power area than a flatter demand curve ceteris paribus.

The market conduct of rice sellers is another viewpoint. In the study of PSA on Marketing Costs Structure for Palay/Rice 2013, 78\% of the farm-operators responded that buyers usually set the price, and only $12 \%$ claimed that farmers and traders agreed on the selling price. On the side of the traders, $75 \%$ of the traderrespondents claimed that they set the price. Only $17 \%$ said that price was based on an agreement between buyers and traders (PSA 2015).

\section{CONCLUSIONS}

There is market power in the Philippine rice industry and it is more apparent in groups where the inelasticity of demand is higher.

The indicator $(\lambda)$ for the presence of market power revealed its reality in nonmajor rice-producing regions for both types of rice (WMR \& RMR) and for RMR in major rice-producing areas. A lambda $(\lambda)$ in between 0 and 1 signifies a CournotNash market structure in the Philippine rice industry. Based on the coefficient of market power, the major rice-producing regions are behaving near monopoly with almost 1 for RMR (-0.99) as compared to non-major producing regions with only 0.70 .

One of the most important observations is the price elasticity of demand. It was revealed that the more the demand curve becomes inelastic from 0.8 to 0.6 , the more the market power becomes apparent. The steeper demand curve for RMR in 
both regions and WMR in non-major rice-producing regions may have triggered the inefficient market conduct of rice sellers. When the elasticity of demand is small, mark-up over marginal cost is high and there is more market power. Hence, in terms of market power, the low-income group who are the customers of lower-priced rice (RMR) and WMR consumers in the non-major rice-producing regions were the ones afflicted.

\section{POLICY RECOMMENDATIONS}

Amidst the presence of market power in the Philippine rice industry, the following are recommended to minimize if not solve market power. First, institute policies that would help flatten the demand curve of the industry. For example, facilitation of a massive information campaign regarding more rice substitutes as staples, or more studies on comparable food substitutes for rice. Also, Government programs could be geared towards empowering more palay traders such as the village collectors and rice trader/millers who are palay buyers to effect a more elastic demand curve. The retail price of rice is highly influenced by the farmgate price of palay. The mark-up set by retailers is fairly set. In addition, the influence of palay traders in the market can be minimized through producer/farmer power. The bulk of palay is bought based on quality, eg, sold dried or wet. Most farmers do not have good drying facilities therefore they sell wet palay at a much lower price. Hence, the provision of drying facilities in key areas is commendable. In addition, farmers could be organized by objective, or form a cooperative or farmers' organizations exclusive for rice farmers for harmony and focused group activities. They may be trained to operate as industry clusters to foster efficiency in the supply chain and get a fair share for their produce.

Lastly, the results of this study should be further validated - for instance, a model for a) high-income rice surplus region; b) low-income rice surplus region; $c$ ) high-income rice deficit region, and low-income rice deficit region. Any established information on this matter would help government policy-makers craft courses of action, alleviating the economic hardships of disadvantaged groups in society who depend so much on rice for their nourishment.

\section{REFERENCES}

Bresnahan TF. 1982. The Oligopoly Solution Concept is Identified. Economics Letters 10:87-92. North Holland Publishing Company

Deodhar SY and Sheldon IM. 1997. Market Power in the World Market for Soymeal Exports. Journal of Agricultural and Resource Economics 22(1):78-86

Digal LN. 2011. Market Power in the Philippine Retail and Processed Food Industry, Journal of International Food \& Agribusiness Marketing 23(4):289-309

Gujarati D. 2004. Basic Econometrics (4th edn). McGraw-Hill Companies

Intal PS Jr, Cu LF \& Illescas JA. 2012. Rice Prices and the National Food Authority. Philippine Institute for Development Studies (PIDS). Discussion Paper Series No. 2012-27

Intal PS Jr and Ranit LO. 2001. Literature Review of the Agricultural Distribution Services Sector: Performance, Efficiency and Research Issues. Philippine Institute for Development Studies (PIDS). Discussion Paper Series No. 2001-14 


\section{Is there a market power in the Philippine}

Kang H, Kennedy PL \& Hilbun B. 2009. Structure and Conduct of the World Rice Market. A paper presentation at the Southern Agricultural Economics Association annual meeting, Atlanta, Georgia

Karp LS and Perloff JM. 1989. Dynamic Oligopoly in the Rice Export Market. The Review of Economic and Statistic 71(3):462-470

Lantican FA, Sombilla MA \& Quilloy KP. 2013. Estimating the Demand Elasticities of Rice in the Philippines. Published by SEARCA, Los Baños, Laguna, Philippines

Lau LJ. 1982. On Identifying the Degree of Competitiveness from Industry Price and Output Data. Economic Letters 10:93-99

Matriz MJR. 2008. Price Transmission Mechanism in the Philippine Rice Industry (MSThesis). University of Delaware

Nwachukwu IN, Onyenweaku CE, Nwaru JC \& Paveliuc-Olariu C. 2011. Measuring the Degree of Market Power in the Export Demand for Nigerian Cocoa: An Analysis of Dutch Market. Journal of Social and Development Sciences 2(3):94103

Perloff JM, Karp LS \& Golan A. 2007. Industry Models of Market Power. Estimating Market Power and Strategies. Cambridge University Press

Philippine Statistics Authority (PSA). 2015. Marketing Costs Structure for Palay/Rice 2013

Philippine Statistics Authority (PSA). http://www.countrystat.psa.gov.ph. \& http://philfsis.psa.gov.ph

Ramos EV. 2013. A Time Series Analysis of Intertemporal Price Transmission in the Philippine Rice Market. 12th National Convention on Statistics, October 2013

Reeder MM. 2000. Asymmetric Prices: Implications on Trader's Market Power in Philippine Rice. Journal of Philippine Development 27(1) First Semester

Rufino CC. 2008. Inter-Regional Integration of the Philippine Rice Market. The DLSUAKI Working Paper Series 2008-06. De La Salle University-Manila, Philippines

Stock JH. 1987. Asymptotic Properties of Least Squares Estimators of Cointegrating Vectors. Econometrica 55(5):1035-1056

Umali DL. 1990. The structure and price performance of the Philippine rice marketing system (PhD dissertation). Stanford University, California

Umali DL and Duff B. 1992. The Philippine Rice Marketing System: Implications for Grain Quality Improvement. Consumer Demand for Rice Grain Quality. Terminal Report of IDRC Projects National Grain Quality (Asia) and International Grain Quality Economics (Asia)

Wailes EJ and Chavez EC. 2012. ASEAN and Global Rice Situation Outlook. ADB Sustainable Development Working Paper Series, No. 22, August 2012

Yao RT, Shively GE \& Masters WA. 2007. How Successful Are Government Interventions in Food Markets? Insights from the Philippine Rice Market. Philippine Journal of Development 34(1) First Semester 2007 
Bellezas et al

Appendix Table 1a. Multivariate co- integration tests of the variables in the demand function of rice in major and non-major rice producing regions

\begin{tabular}{|c|c|c|c|c|c|c|c|c|}
\hline \multirow{2}{*}{$\begin{array}{l}\text { Cointegrating } \\
\text { Rank }\end{array}$} & \multicolumn{4}{|c|}{$\begin{array}{l}\text { Major Rice Producing } \\
\text { Regions }\end{array}$} & \multicolumn{4}{|c|}{ Non-Major Rice Producing Regions } \\
\hline & $r=0$ & $r \leq 1$ & $r \leq 2$ & $r \leq 3$ & $r=0$ & $r \leq 1$ & $r \leq 2$ & $r \leq 3$ \\
\hline \multicolumn{9}{|l|}{ Well-milled rice } \\
\hline Eigenvalue & & 0.416 & 0.324 & 0.234 & & 0.437 & 0.398 & 0.296 \\
\hline Trace statistic & 173.08 & $119.3^{*}$ & 80.15 & 53.52 & 196.51 & 138.53 & $87.30 *$ & 51.87 \\
\hline Max statistic & 53.77 & 39.16 & 26.62 & 24.87 & 57.98 & 51.23 & 35.44 & 20.61 \\
\hline \multicolumn{9}{|l|}{ Regular-milled rice } \\
\hline Eigenvalue & & 0.4089 & 0.369 & 0.240 & & 0.451 & 0.397 & 0.312 \\
\hline Trace statistic & 176.85 & 124.28 & $78.28 *$ & 50.89 & 202.13 & 141.51 & $90.41^{*}$ & 52.69 \\
\hline Max statistic & 52.58 & 45.99 & 27.40 & 23.89 & 60.62 & 51.10 & 37.72 & 22.34 \\
\hline 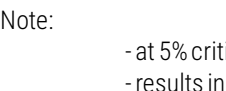 & & 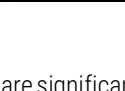 & & & & & & \\
\hline
\end{tabular}

Appendix Table 1b. Multivariate co- integration tests of the variables in the supply relation of rice in major and non-major rice producing regions.

\begin{tabular}{|c|c|c|c|c|c|c|c|c|c|}
\hline \multirow{2}{*}{$\begin{array}{l}\text { Cointegrating } \\
\text { Rank }\end{array}$} & \multicolumn{4}{|c|}{$\begin{array}{c}\text { Major Rice Producing } \\
\text { Regions } \\
\end{array}$} & \multicolumn{5}{|c|}{$\begin{array}{c}\text { Non-Major Rice Producing } \\
\text { Regions } \\
\end{array}$} \\
\hline & $r=0$ & $r \leq 1$ & $r \leq 2$ & $r \leq 3$ & $r=0$ & $r \leq 1$ & $r \leq 2$ & $r \leq 3$ & $r \leq 4$ \\
\hline \multicolumn{10}{|l|}{ Well-milled rice } \\
\hline Eigenvalue & & 0.376 & 0.319 & 0.240 & & 0.348 & 0.291 & 0.259 & 0.192 \\
\hline $\begin{array}{c}\text { Trace } \\
\text { statistic }\end{array}$ & 137.20 & 89.55 & 50.69 & $22.97 *$ & 136.64 & 93.50 & 58.79 & $28.48 *$ & 6.97 \\
\hline $\begin{array}{r}\text { Max } \\
\text { statistic }\end{array}$ & 47.62 & 38.86 & 27.72 & 16.14 & 43.14 & 34.71 & 30.31 & 21.51 & 6.94 \\
\hline \multicolumn{10}{|l|}{$\begin{array}{l}\text { Regular-milled } \\
\text { rice }\end{array}$} \\
\hline Eigenvalue & & 0.416 & 0.334 & 0.207 & & 0.359 & 0.308 & 0.199 & 0.116 \\
\hline $\begin{array}{c}\text { Trace } \\
\text { statistic }\end{array}$ & 140.40 & 86.61 & $45.96^{*}$ & 22.80 & 123.82 & 79.34 & $42.57^{*}$ & 20.38 & 8.049 \\
\hline $\begin{array}{r}\text { Max } \\
\text { statistic } \\
\end{array}$ & 53.79 & 40.65 & 23.16 & 14.59 & 44.42 & 36.82 & 22.19 & 12.33 & 8.023 \\
\hline
\end{tabular}

